\author{
Ю. О. Арешенков
}

канд. філол. наук, професор

\title{
СЛОВЕСНИЙ ОБРАЗ \\ В АСПЕКТІ ЛІНГВІСТИЧНОГО АНАЛІЗУ ТЕКСТУ
}

У статті розглядаються лінгвостилістичні риси словесного образу як основного засобу реалізаиії естетичної функиії мови. Основна увага приділяється з'ясуванню специфіки мовного механізму утворення тропів через незвичну сполучуваність слів, що забезпечує актуалізаиію художнього вислову.

Фаховий потенціал філолога, його професійні знання і вміння мають реальну суспільну вартість переважно при вирішенні таких практичних завдань, як створення комунікативно довершених текстів (що є прерогативою стилістики) та адекватна інтерпретація художніх творів (на основі лінгвостилістичного аналізу).

Пильна увага сучасної лінгвістики до художнього тексту викликана потребою більш грунтовно дослідити механізм його мовної організації, з'ясувати лінгвістичну природу тих естетичних явищ, які традиційно розглядалися літературознавчою стилістикою, поетикою, риторикою. «Текст у всій сукупності своїх внутрішніх аспектів та зовнішніх зв'язків, - зазначав акад. С. С. Аверинцев, - $\epsilon$ вихідною реальністю філології. Зосередившись на тексті, створюючи до нього службовий «коментар», філологія під цим кутом зору вбирає в свій круговид всю широту та глибину людського буття, насамперед буття духовного» [5, 372]. В першу чергу це стосується тексту художнього, оскільки він має ряд специфічних рис, зокрема: містить не лише семантичну, але й естетичну (художню) інформацію, в якій виражається емоційно-оцінне та експресивно-оцінне ставлення до зображуваного; має абсолютну антропоцентричність, коли все зображуване моделюється для пізнання людини; є принципово полісемантичним (неоднозначним) за наявності інваріантного ядра; характеризується імпліцитністю, тобто прихованим у підтексті змістом, що створює семантичну багатоплановість твору.

Текстові нехудожньому з психолінгвістичного погляду притаманний автоматизм, тобто звичне (узуальне) вживання мовних засобів, що забезпечує легке й безпосереднє їх сприйняття. Іншими словами, у мовленні практичному свобода вибору дуже обмежена, і кожен наступний елемент висловлення зумовлюється правилами або закономірностями побудови, що властиві саме цьому функціональному різновидові. 
Художньому текстові навпаки - притаманна актуалізація, тобто незвичне використання певних мовних засобів, що привертає до них увагу читача/слухача. Художник слова навмисне йде на порушення мовної норми: «Поетичний текст - потужний і глибоко діалектичний механізм пошуку істини, тлумачення довколишнього світу та орієнтації в ньому. У світ мовного автоматизму поезія вносить свободу» $[3,131]$. При цьому високохудожній текст відзначається високим рівнем естетичності - згармонізованості форми викладу з його змістом, найдоцільнішим добором мовних засобів.

Актуалізація мовних засобів виявляється передовсім у незвичному поєднанні слів. У принципі лексична сполучуваність буває звичною (усталеною, унормованою) і незвичною. Своєю чергою, незвичне поєднання може бути можливим або неможливим, напр.:

1) У сестри дівочі коси - звичне поєднання;

2) У стільия дівочі коси - незвичне і неможливе;

3) У верби дівочі коси - незвичне, але можливе.

Словосполучення коси стільия є неможливим, насамперед, з логічних підстав. Між тим, логічна аргументація відступає у випадку (3). Хоч у семантичній структурі слів коса і верба немає однакових сем, їх сполучення стає реальним завдяки можливому співвіднесенню 3 третім, евентуально спільним словом. Якщо розгорнути метафоричне словосполучення «коси верби», то воно набуде форми «віти верби - довгі, тонкі, красиві, наче ко$\underline{c u}$ дівчини». Як видно, спільним елементом тут $є$ схожа ознака, і ми можемо віти назвати «косами», якщо їхня схожість $є$ для нас вирішальною. Таким чином, логічна структура образного висловлення включає: суб'єкт порівняння (С) + підставу, спільну ознаку (П) + об'єкт порівняння (О).

Найбільш очевидний висновок полягає в тому, що напіввідмічені структури (з непередбачуваною лексичною сполучуваністю) здатні передавати інформацію значно щільніше за структури відмічені, із звичними зв'язками між словами. Не менш важливою є відмінність між ними в емоційно-психологічному плані:

- нейтральне повідомлення, стандартне за своєю формою, швидше всього залишить читача (слухача) байдужим - коси дівчини;

- фраза, в якій трапилося незвичне, але контекстуально й логічно невмотивоване поєднання слів, звучить абсурдно, а отже - незрозуміло, а тому може викликати лише неприйняття і роздратування - коси стільия;

- емоційно привабливими виглядають незвично сполучені слова, смисловий зв'язок між якими може бути встановлений 3 допомогою третього слова - коси верби.

Крім позитивної емоційної реакції, образні висловлення здатні збільшувати мережу зв'язків у власному тезаурусі людини і тим самим збільшувати потенціал його знань. Відомо, що між словами існують постійні асоціативні зв'язки, що виникають на основі схожості (темний - чорний, гора - кряж), контрасту (темний - світлий, верх - низ), зміщення (стіл - 
стілець), розширення (стіл - меблі, сарай - будова), звуження (меблі стіл, будова - сарай), переносу (стілець - сидіти, співати - пісні).

Від постійного вживання слова ніби знецінюються, зменшується їхня інформативність, відбувається так звана «семантична насиченість». Потрапляючи в незвичний контекст, слово здатне поновлювати свою яскравість та виразність. За словами Г. Голіцина, «намагаючись відійти від банальності, підвищити інформативність та виразність мовлення, мова постійно творить нові шати для речей» $[2,32]$. Таке оновлення відбувається не лише завдяки неологізмам, але й «неосемантизмам»- традиційним словам, наділеним новим смислом.

Нові контексти, в яких слова здатні висвітлюватися новими смислами, $\epsilon$ основою для створення словесних образів.

Мовні одиниці самі по собі образності не мають, вони співвідносяться iз дійсністю як знаки. Спілкуючись, ми намагаємося висловлюватися так, щоб нас зрозуміли правильно, однозначно, і це є загальною комунікативною стратегією практичного мовлення. У мовленні художньому метою автора $є$ не стільки однозначність, скільки оригінальність висловлення, яка досягається передовсім образним вживанням слів. Свою потребу одержувати нову інформацію людина може задовольняти або одержуючи їі безпосередньо із довкілля або рекомбінуючи елементи попередніх вражень за допомогою творчої уяви. Однак позитивні емоції може викликати (і це підтверджено психологічними дослідами) лише помірна ступінь новизни, коли нове оптимально поєднується з відомим. Несподіваність і незвичність мають виділятися на фоні певної норми спільних ознак, які зближують новий об'єкт з іншими спорідненими.

Мовна образність виникає за умови особливого поєднання, семантичного зв'язку між мовними одиницями, коли експонент (форма) одного мовного знака асоціюється із значенням (змістом) іншого. Наприклад, у фразі Зелені коси верби звуковий комплекс [ко́сu], зберігаючи асоціації з денотатом «довге волосся», набуває нового, переносного значення - «відгалуження дерева», - яке звичайно передається словом віти. Така взаємодія різних слів створює своєрідну стереоскопічність сприйняття, породжує словесний образ: названо не просто «віти», а «віти довгі, тонкі, красиві».

На відміну від нехудожнього слова, слово поетичне (художнє) не лише щось позначає, але й виражає певне ставлення до зображуваного - несе естетичну модальність. Крім семантичного компонента, тобто смислової інформації, в ньому обов'язково наявний модальний компонент, інформація естетична. Причому, модальність може бути як позитивною, так і негативною, пор.: віти-коси:: віти-батоги.

Логічна структура словесного образу, тобто слова або словосполучення, що несуть образну інформацію, складається із суб'єкта (означуване), об'єкта (означник) та підстави порівняння, напр.: Коси верби = С (віти верби) + П (довгі, тонкі, красиві...) + О (як коси). 
Інформація у словесному образі є завжди більшою за просту суму значень окремих компонентів, узятих поза контекстом. Так, коси верби це не просто «віти верби», а «віти довгі, тонкі, красиві...», пор.:

Віти верби $=\langle$ Віти $\rangle+\langle$ Верба $»$

Коси верби = «Віти» + «Довгі, тонкі, красиві...» + «Верба»

Таким чином, під образністю слід розуміти властивість поетичного мовлення передавати емоційно відтворювану інформацію за допомогою системи словесних образів.

Ширшим за поняття словесного образу є поняття образу художнього, тобто певної моделі дійсності, що відновлює одержану із реальності інформацію в новій сутності. Цей феномен $є$ формою відображення дійсності в світлі естетичних ідеалів митця з допомогою його творчої фантазії.

Система художніх образів здатна конструювати модель реальності порізному, залежно від функції, яку образ переважно виконує в рамках певного художнього методу. Серед цих функцій назвемо такі:

- функція дзеркальна - образ копіює реальність (натуралізм, реалізм);

-функція лакувальна - образ приховує, маскує реальність (соцреалізм);

- функція деформування - образ руйнує реальність (абстракціонізм, авангардизм);

-функція симулювання - образ замішує реальність, стає важливішим за неї (сюрреалізм);

•функція дублювання - образ імітує реальність (гіперреалізм, поп-арт).

Поняття образу є одним із центральних як для теорії літератури, так i для лінгвостилістики через визначальну роль у структурі художнього твору. Без образу немає мистецтва, зокрема поезії. За всієї своєї категоричності, це твердження не перестає бути науково істинним, адже образність $\epsilon$ неодмінним атрибутом художності: «Без надзвичайної складності, конкретності немає образу. Певна множинність рис і міцність їхнього зв'язку, тобто легкість, з якою їхня сукупність охоплюється й зберігається тим, хто розуміє, є мірою художності» [4, 284].

Як бачимо, мовний механізм утворення тропів доволі простий і очевидний: вони виникають у результаті перенесення назви з одного предмета (денотата) на інший, тобто заміни прямого значення на переносне. Саме ж перенесення назви, або перейменування, може відбуватися на основі схожості, подібності властивостей й ознак одного предмета іншому - метафоризація - або їхньої суміжності що виявляється у внутрішньому чи зовнішньому зв'язку між денотатами - метонімія. Перенесення за ознакою кількісного співвідношення - синекдоху - можна розглядати як різновид метонімії, і тому подальша класифікація тропів $є$ елементарною деталізацією двох засадничих підстав: схожості і суміжності.

Метафора являє собою приховане, або згорнуте порівняння. Власне порівняння - це стилістичний прийом, заснований на частковому уподібненні двох предметів (або їхніх властивостей), що належать до різних кла- 
сів, у результаті чого увиразнюється сприйняття першого з них. Порівняння обов'язково має двочленну будову: 1) те, що порівнюється, і 2) те, з чим порівнюється. У метафорі перший компонент порівняння (суб'єкт), як правило, випускається, але шляхом імплікації його можна відновити і трансформувати метафору у порівняння. Наприклад, метафори з поезії Ліни Костенко планети бджіл в туманностях пилку можна розгорнути за такою логікою:

Планети бджіл $\leftarrow$ бджоли, як планети $\leftarrow$ рої-планети $\leftarrow$ рої бджіл, як планети;

Туманності пилку $\leftarrow$ пилок, як туманності $\leftarrow$ клуби-туманності $\leftarrow$ клуби пилку, як туманності.

аналізу інтерес становлять лише індивідуально-авторські метафори.

На основі метафоризації слів виникають інші види тропів, зокрема гіпербола, тобто навмисне перебільшення зображуваного з метою його увиразнення: з '̈сти гору горіхів. Увиразнити зображуване можна і непомірно зменшивши його, напр.: з їсти крихту пирога - літота.

Для розуміння і правильного визначення метонімії слід знати, що суміжність існує у різних реальних відношеннях між предметами - просторових, часових, логічних, ситуативних - і може виявлятись у зв'язках між матеріалом і виготовленою з нього річчю, між місциною та ії мешканцями, між процесом та його результатом, між дією та знаряддям тощо. Напр.: бронза Богдана $\leftarrow$ бронзовий пам'ятник Богдану.

Перенесення назви $з$ цілого на частину або з загального на часткове, що називають синекдохою, є також різновидом метонімії, кількісного співвіднесення денотатів. Найпростіший приклад синекдохи - вживання однини замість множини чи навпаки. Складніші випадки, коли назва частини виступає замість назви цілого, родова назва замість видової, а видова замість родової, напр.: мріяти про обручку $\leftarrow$ мріяти про одруження.

Крім зображальних засобів, якими $є$ тропи, в художньому мовленні активно використовуються засоби виражальні, які називаються стилістичними фігурами. Це особливі синтаксичні звороти, що посилюють виразність висловлювання завдяки незвичності синтаксичної побудови.

Якщо тропи виникають внаслідок переносного вживання лексичних одиниць, то фігури мають синтагматичну природу: грунтуються на лінійному розташуванні компонентів речення. Певний стилістичний ефект створюється завдяки тому, що елементи синтаксичної структури можна а) додавати, б) випускати, г) переставляти. Відповідно до цього виникають три групи виражальних засобів: фігури, засновані на розширенні структури за рахунок повтору іiї компонентів (синтаксичній мультиплікації) - повтор, полісиндетон, ампліфікація, градація; фігури, засновані на редукції структури речення (синтаксичній компресії) - еліпсис, умовчання, асиндетон; фігури, засновані на зміні порядку розташування компонентів - інверсія. 
Між тропами та фігурами існує важлива відмінність, на якій слід обов'язково наголосити. Тропи $є$ формою поетичного мислення і вони збагачують думку новими смислами: пряме, звичайне значення слів у тропі руйнується і не перший план висуваються значення периферійні, асоціативні. Фігури ж є формою мовлення, вони не розширюють наше пізнання, але посилюють враження від висловленого. Психологія людського сприйняття $є$ такою, що всяка нестандартність, незвичність привертає до себе увагу і здатна викликати емоційно-естетичні почуття. «У всякому тексті, зазначає I. В. Арнольд, - діють дві протилежні, але взаємопов'язані тенденції. Це тенденція до посилення експліцитності (розгорнутості), наприклад, до повтору, який полегшує сприйняття та запам'ятовування, і тенденція до компресії інформації та сугестивності (навіювання), яка збільшує активність співтворчості читача, а також посилює експресивність й естетичний вплив» $[1,104]$. Більшість стилістичних фігур є різновидами повтору - повторення слів, словосполучень чи конструкцій для посилення їхнього сприйняття.

Повторюваність як конструктивний принцип використовується і при створенні різних засобів фонетичного, а також метро-ритмічного рівня. Більш предметно вони розглядаються у фоностилістиці та поетиці і беруться до уваги при лінгвостилістичному аналізі, тому дослідникові слід орієнтуватися в основних поняттях метрики та фоніки і вміти характеризувати їх. I все ж в процесі лінгвістичного аналізу основна увага має приділятись образним засобам, оскільки саме вони здатні безпосередньо формувати семантичну інформацію тексту і слугувати знаряддям вираження художнього концепту - смислового ядра твору, на виявлення якого і спрямовується весь потенціал цієї важливо необхідної процедури дослідження словесної художньої творчості.

\section{Список використаної літератури}

1. Арнольд И. В. Стилистика современного английского языка. - 3-е изд. - М., 1990.

2. Голииын Г. А. Информация - логика - поэзия // Число и мысль. Сборник. Вып. 7. - М.: Знание, 1984.

3. Лотман Ю. М. Анализ поэтического текста. - Л., 1972.

4. Потебня О. Естетика і поетика слова. - К., 1985.

5. Русский язык: Энциклопедия. - М., 1979.

\section{Summary}

In the article, the linguistic lines of verbal appearance are examined as a basic mean of realization of aesthetically beautiful function of language. Basic attention is spared finding out of specific of linguistic mechanism of formation of tropes through unusual compatibility of words of, which provides actualization of artistic utterance. 